\title{
Design for learning in the third space: opportunities and challenges
}

\author{
Simona Ferrari ${ }^{\mathrm{a}}$, Serena Triacca ${ }^{\mathrm{b}}$, Gianluca Braga ${ }^{\mathrm{c}}$ \\ ${ }^{a}$ Catholic University of the Sacred Heart, Italy, simona.ferrari@unicatt.it \\ https:/lorcid.org/0000-0003-3736-1320 \\ ${ }^{b}$ Catholic University of the Sacred Heart, Italy, serena.triacca@unicatt.it, \\ http://orcid.org/0000-0001-8854-5117 \\ ${ }^{c}$ Catholic University of the Sacred Heart, Italy,gianluca.braga@unicatt.it
}

\begin{abstract}
Many educational agents offer paths that allow school to turn itself into a 'third space'. Caritas Ambrosiana, based on a 'pedagogy of facts', proposes interventions to promote soft skills in schools. This non-formal education agency committed Research Center about Media Education, Innovation and Technology (CREMIT) of Catholic University for a project to improve their school programme and training effectiveness. We chose the participatory action research paradigm to verify how to design an educational path by applying third-space principles in the school context and how digital media can be embedded into the practice to enable a more porous exchange of experiences and expertise between students, educators and the school curriculum.

The accompanying plan was designed on the basis of the initial questionnaire data analysis: sociomateriality was the main focus because it was considered by Caritas educators as one of the least important elements to include in the design process. The second reason is the need to rethink on-site training formats to face the challenges of the Covid-19 emergency.

As expected, after the training intervention, sociomateriality had a significant growth in the design practices. The other third-space pedagogy elements (peering, experiential orientation, motivation, pleasure of making together) are maintained and reinforced, thanks to digital literacy.
\end{abstract}

Keywords: action research; design; third space

\section{Towards a third-space pedagogy}

Many educational initiatives, labelled as non-formal education ${ }^{1}$ (Hamadache, 1991; Hoppers, 2006) or lifelong learning (Field, 2000) or currently open education, seem naturally oriented to practice a 'third-space' literacy as proposed by Potter and McDougall (2017). It deals with three important pillars: dynamic literacy, third space and curation.

Dynamic literacies are 'emergent literacies which are sociocultural in nature, located in the spaces, actions and practices of digital media' (ivi, p. 34). They reflect the 'changing nature of teaching and learning in response to the widespread consumption and production of digital media texts and artefacts in wider culture' (ivi, p. 16). The authors bring together sociocultural (sociomateriality and third-space) literacies and semiotic (textual and design) literacies underlining the dual nature: 'synchronic, inclusive of current situated practices, and diachronic, a term which opens the possibility of movement through time as incorporated principle' (ivi, p. 36). Dynamic literacies are fruitful, located in third space (Bhabha, 1990, 1994; Soja, 1996): a space or a metaphorical location 'in which meanings are made and shared, some of which may relate to encountering new knowledge, learning or developing new skills and dispositions' (Potter \& McDougall, 2017, p. 17). As written by Woolf, 'third space theory builds on the metaphor of space to illustrate the fluid intersections of identity, culture, and socially produced knowledge' (Woolf, 2019, p. 3).

1 'Characteristics of non-formal education: (a) it consists of organized, structured activities (otherwise it would be classified as informal); (b) it is designed for an identifiable target group; (c) it is organized to achieve a specified set of learning objectives; and (d) these non-institutionalized activities are carried out outside the established education system and are intended for learners who are not officially enrolled in school (even if in some cases learning takes place in a school setting)' (Hamadache, 1991, p. 113). 


\section{Design for learning in the third space: opportunities and challenges}

Ferrari,S., Triacca, S., Braga,G.

'The first space is everyday life experience (self, home, community) and represents the cumulative impacts of socio-cultural experiences and the core cultural beliefs produced across diverse communal enterprises. The second space encompasses cognitively construed ideologies, norms, and priorities acquired through formalized training' (ibidem). The second space is usually actualised in formal education; generally, it is in school. The third space is generally defined as ' $[1 / 4]$ the area between official curriculum and informal knowledge, with skills and dispositions brought in from outside culture' (Potter \& McDougall, 2017, p. 87). It is 'a place of invention and transformational encounters, a dynamic in between space that is imbued with the traces, relays, ambivalences, ambiguities and contradictions, with the feelings and practices of both sites, to fashion something different, unexpected' (Bhabha, 1994, p. 406). We like to think of it as a popular culture.

Curation, previously seen as 'porous expertise' (McDougall \& Potter, 2015), is the third concept that brings the ideas of dynamic literacies and third spaces together. It is 'a concept which addresses a key issue in the digital age, namely that of "powerful knowledge" and how this may be encountered and negotiated' (Potter \& McDougall, 2017, p. 6), that requires reflexive literacy practice and meta-authorship. It is a new literacy practice, 'an umbrella, meta-level activity that subsumes collecting, cataloguing, arranging and assembling for exhibition and which, to some degree, subsumes smaller editorial acts of selection within it' (ivi, p. 7).

These three pillars design a new pedagogical scenario. We try to operationalise them and turn into learning actions to be able to frame a 'third-space' pedagogy. Revisiting Digital Media, Culture and Education: Theorising Third Space Literacies, we can underline the necessity to:

- design agentive activity, 'literacy events' (Street, 2003) in which meanings are shared through an act of social 'cultural performance' (Bhabha, 1994) and through creative and challenging practice. These could cover technical, critical, creative and ethical practices from an authorial point of view;

- enable exchange of expertise between adult and guys and among guys in a horizontal relation, engaging them in the negotiated third space and in the co-creation process;

- elaborate strategies of selfhood and of innovative sites of collaboration and contestation where students feel free 'to explore a more interest- and learner-driven agenda' (Potter \& McDougall, 2017, p. 53) and where narrative process will benefit of digital affordances in spreadable ways;

- value and activate the potential for digitally mediated cultural practices;

- grant access and support for equity and social justice.

In our research, we will explore these aspects assuming the way Rivoltella (2020) focuses them in education: peering, experiential orientation, motivation, pleasure of 'doing together', sociomateriality, absence of assessment and certification.

The first research idea is to consider these elements as conditions of third space that may challenge 'signature pedagogies'. We verify them analysing pedagogical practices and introduce them in training of trainers to foster digital media literacy in a dynamic way.

The second one deals with the idea of Potter and McDougall that the third space can be generated in the second space. This means to reflect on conditions that allow and transform the school systems - formal learning, curriculum-centred, away from learners' lived experience, not fully agentive approach, almost based on replication and reinforcing outcomes, vertical regime of value/legitimation - in a 'third space'.

The opportunity came from Caritas Ambrosiana², a non-formal education agency based on a 'pedagogy of facts' (Savagnone, 2009), which promotes soft skills in school interventions, bearing witness to the specific areas of need on which it operates. It is a foundation of pastoral organisation active since 1963 to support the most vulnerable people and to promote the importance of concrete actions for the poor. It has a 'predominant pedagogical function' (Art. 1) ${ }^{3}$ focused on witness, person and community; it works for justice and peace. Partnering with the Italian Ministry of Education (MIUR), it works to support students and youth groups to become empowered to stand up to end poverty and promote justice. Caritas turns to the Catholic University for a third mission project to improve school programme and training effectiveness. Research Center about Media Education, Innovation and Technology (CREMIT) saw in Caritas that 'semi-permeable membrane' that allows schools to become a third space and in fostering Caritas' digital practices is a way to make it more porous.

\section{Method and research design}

Specificity of this project shapes the research process and leads to choose the participatory action research paradigm.

\subsection{Research plan and tools}

The main characteristics of action research - '[1/4] its practical nature, its focus on change, the involvement of a cyclical process, its concern with participation' (Denscombe, 1998, pp. 57-58) - comply with our research questions that are:

- Q1. How can Caritas Ambrosiana handle an educational project by applying third-space principles in the school context? (stages 1-4);

\footnotetext{
${ }^{2}$ https://caritasambrosiana.it/

${ }^{3}$ https://tinyurl.com/87nz6tt5
} 


\section{Design for learning in the third space: opportunities and challenges}

Ferrari,S., Triacca, S., Braga,G.

- Q2. How can digital media be embedded into practice to enable a more porous exchange of experiences and expertise between students, educators and the school curriculum? (stages 4-5) and

- Q3. Could the changes in the educational projects be generative of dialogue, construction and creativity (Potter \& McDougall, 2017, p. 43)? (stages 6-8).

Reviewing the different action research models (Costello, 2003), the project adopted that of Bassey, who defines educational action research as ' $[1 / 4]$ an enquiry which is carried out in order to understand, to evaluate and then to change, in order to improve some educational practice aimed at informing educational judgments and decisions in order to improve educational action' (Bassey, 1998, p. 93).

Action research provides a way to enable two aims to be achieved for educators as reflective practitioners (Schon, 1987, 1991): engaging the educators in the study of their own practice and developing their own educational theories derived for that practice. Being a reflective practitioner is the first condition for understanding and generating the third space. Potter and McDougall state that this arises out of the skilled pedagogical practices of the educators and co-researchers (2017, p. 45).

Bassey's framework consists of eight stages (Bassey, 1998, pp. 94-95) that we applied to Caritas Ambrosiana context:

- Stage 1. Defining the enquiry: At this stage, we reflected about the conditions and constraints of working in the school context from Caritas Ambrosiana's point of view to highlight the relationship between formal and informal; we also presented and negotiated the action research project (January-February 2020).

- Stage 2. Describing the educational situation: At this stage, we collected information about Caritas Ambrosiana pedagogical approach, training offers for schools ${ }^{4}$, self-presentations of the 30 educators involved (February 2020).

- Stage 3. Collecting and analysing evaluative data: At this stage, a questionnaire was administered and educational projects were analysed, focusing on the design practices (March-June 2020).

- Stage 4. Reviewing the data and looking for contradictions: The researchers designed the accompanying plan (June 2020).

- Stage 5. Tackling a contradiction by introducing some aspect of change: We discussed about digital as a way of defining or redefining communication in teaching and learning process, highlighting this act as a cultural performance and a production of meaning (Bhabha, 1994) (July-October 2020).

- Stage 6. Monitoring the change: Introduction of the third-space framework and presentation of logbook for educators and cultural probe tools for students (moodboard, random thoughts box). These tools will give the researchers the opportunity to collect the emic views (Lincoln \& Guba, 1985) (September-December 2021).

- Stage 7. Analysing evaluative data concerning the change: Cultural probes analysis (Spiridonidou et al., 2010) (January 2022)

- Stage 8. Reviewing the change and deciding what to do next (February 2022)

In this paper, we present and discuss data collected up to Stage 5.

According to the action research plan outlined above, the main focus points of analysis are context, design practices and educational changes. The tools adopted are summarised in Table 1.

Specifically, for the first focus (context), we made use of:

- document analysis (Bowen, 2009) and

- educators' self-presentations, guided by three key questions (How long have you been a Caritas operator? What inspires you in planning your activities? What are the strengths and areas for improvement?).

- For the second focus (design practices), we made use of:

- educational projects analysis, structured with reference to third-space elements focused by Rivoltella (2020) in education, as previously described. In general, non-formal education includes evaluation, but not assessment; so we exclude the last element (absence of assessment and certification) from the grid and initial questionnaire.

Finally, for monitoring and analysing the change and collecting the emic views (Lincoln \& Guba, 1985), we planned:

- educators' logbook analysis,

- cultural probes (Gaver et al., 1999) and

- teachers' interviews.

Table 1. Stages and research tools

\begin{tabular}{lll}
\hline Timing & Stage & Research tools \\
\hline January-February 2020 & Stage 1. Defining the enquiry & Document grid analysis \\
February 2020 & Stage 2. Describing the educational situation & Educators' self-presentation \\
\hline
\end{tabular}

\footnotetext{
${ }^{4}$ https://scuole.caritasambrosiana.it/
} 


\section{Design for learning in the third space: opportunities and challenges}

Ferrari,S., Triacca, S., Braga,G.

\begin{tabular}{|c|c|c|}
\hline Timing & Stage & Research tools \\
\hline March-June 2020 & Stage 3. Collecting and analysing evaluative data & $\begin{array}{l}\text { Design practices analysis } \\
\text { Initial questionnaire }\end{array}$ \\
\hline June 2020 & Stage 4. Reviewing the data and looking for contradictions & \\
\hline July-October 2020 & Stage 5. Tackling a contradiction by introducing some aspect of change & Design practices analysis \\
\hline September-December 2021 & Stage 6 . Monitoring the change & $\begin{array}{l}\text { Logbook } \\
\text { Moodboard and random } \\
\text { thoughts box (cultural } \\
\text { probes) }\end{array}$ \\
\hline January 2022 & Stage 7 . Analysing evaluative data concerning the change & $\begin{array}{l}\text { Logbook grid analysis } \\
\text { Cultural probes grid } \\
\text { analysis } \\
\text { Teachers' interviews }\end{array}$ \\
\hline February 2022 & Stage 8. Reviewing the change and deciding what to do next & \\
\hline
\end{tabular}

\subsection{Data analysis for designing the accompanying plan with the BLEC model}

We start presenting a selection of data collected with the questionnaire that was administered online in the third stage. It provided us with the indispensable elements to design the accompanying plan adopted in Stage 5, which will be explored later.

The initial questionnaire includes questions about demographic and professional information, perception about school context constraints, technological profile, the importance assigned to third-space elements and the degree of activation in educational projects.

Of the respondents $(\mathrm{n}=28), 79 \%$ were female, $78 \%$ were older than 40 years (only six were $<35$ y.0.) and $75 \%$ had been collaborating with Caritas Ambrosiana since at least 10 years, promoting actions to raise awareness, testimonial, information and training on issues related to poverty and fragility, how to intervene and encourage the active commitment of young people with particular reference to specific areas (intercultural education, well-being and relationships, justice and environmental sustainability, etc.) and a wide spectrum of issues related to social phenomena that involve hardships (drugs, HIV, immigration, nomadism, poverty and work, human trade, women's rights, mental health). Projects about people with different cultures and beliefs, living in ever-changing situations, travelling and crossing any kind of limits, are the everyday standards. The respondents usually relate with young students attending primary and secondary schools that do not provide those arguments in their education programme.

We asked them to what extent the school context constraints represent a limit for the training initiatives proposed as Caritas Ambrosiana's operators. The main complaints were about 'space' (i.e. classrooms or other spaces available for the intervention) ( $\mu=3.54$ on a scale of 1-6) more than 'time' (i.e. constraints given by school hours and school times) $(\mu=$ 3.31) or other issues that may limit education in a school setting: formal and vertical relations with students $(\mu=3.08)$, contents apart from the school programme $(\mu=3.08)$, top-down methods (classroom taught lesson and individual work characterises students' expectations) $(\mu=3.27)$ (Fig. 1).

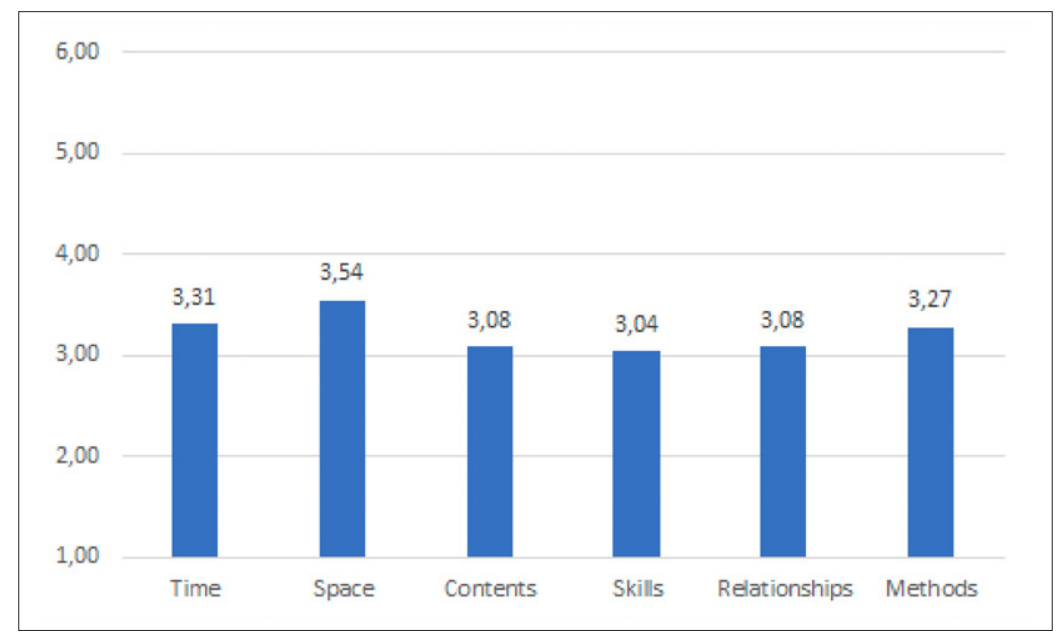

Fig. 1. School context constraints perceived as a limit ( $\mu$ on a scale of 1-6) (source: initial questionnaire)

The first question dedicated to portraying the technological profile of the Caritas Ambrosiana workers asked them to express their own degree of agreement with respect to certain statements about technology. Four claims had a high degree of agreement ( $\mu>4$ on a scale of 1-6) (Fig. 2): 


\section{Design for learning in the third space: opportunities and challenges}

Ferrari,S., Triacca, S., Braga,G.

- 'Technology requires a change in working methods' $(\mu=4.79)$ : This denotes awareness that it is not possible to linearly transpose online or digitally the methods used in a traditional training situation (on-site or in a technology-free context), as the way of planning, managing training activities and assessing is substantially different. This response is in line with the needs expressed by the client, on which to invest in the accompaniment of the operators.

- 'Technology allows me to experiment with innovative training methods (eLearning, Webinar, MOOC)' $(\mu=4.61$ ), 'Technology allows me to keep up to date and informed' $(\mu=4.57)$ : The central role played by technology as an information source and a 'new' way for taking care of lifelong learning is clear. In our context, technology turns out to be both the medium that allows professional development and the subject of learning by practicing with colleagues.

- 'Technology allows me to engage with experts and colleagues from other services' $(\mu=4.14)$ : This denotes the central role of technology as a connective tissue, a way to feel closer to other professionals, learning from each other.

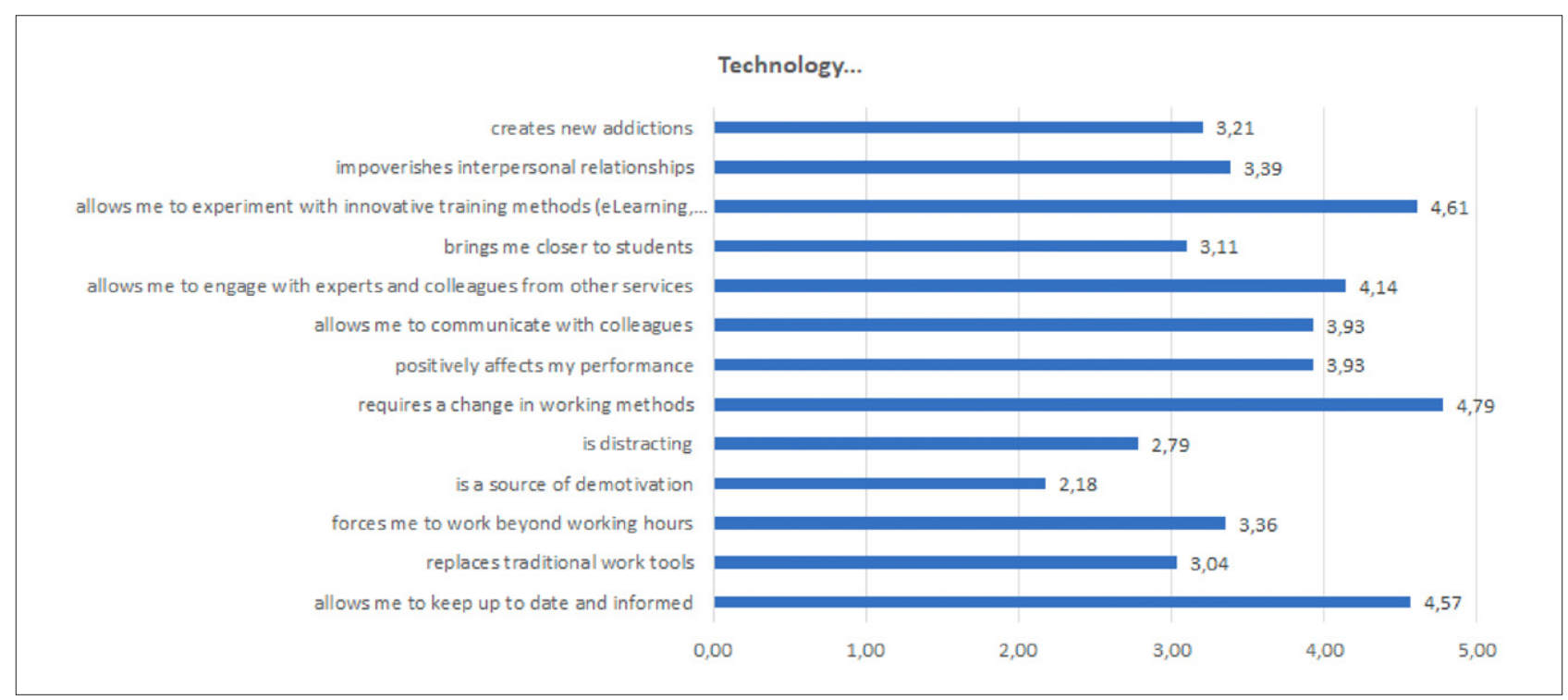

Fig. 2. Representations of technology ( $\mu$ on a scale of 1-6) (source: initial questionnaire)

The participants were then asked to self-assess their digital skills. Overall self-evaluation was positive $(\mu>3.5$ on a scale of 1-6). They felt that they themselves were able to use the web to gather information $(\mu=4.36)$, keeping boundaries between professional and private life $(\mu=4.07)$. They were also quite good on sharing information on the web $(\mu=3.54)$ and collaborating $(\mu=3.50)$. They described themselves as being aware of the use of technological devices $(\mu=3.75)$, but had less knowledge if the utilisation was for educational purposes $(\mu=3.25)$ or implied more specific application as LMS, tools for creating infographics, presentations, quiz, games and so on $(\mu=2.96)$ (Fig. 3).

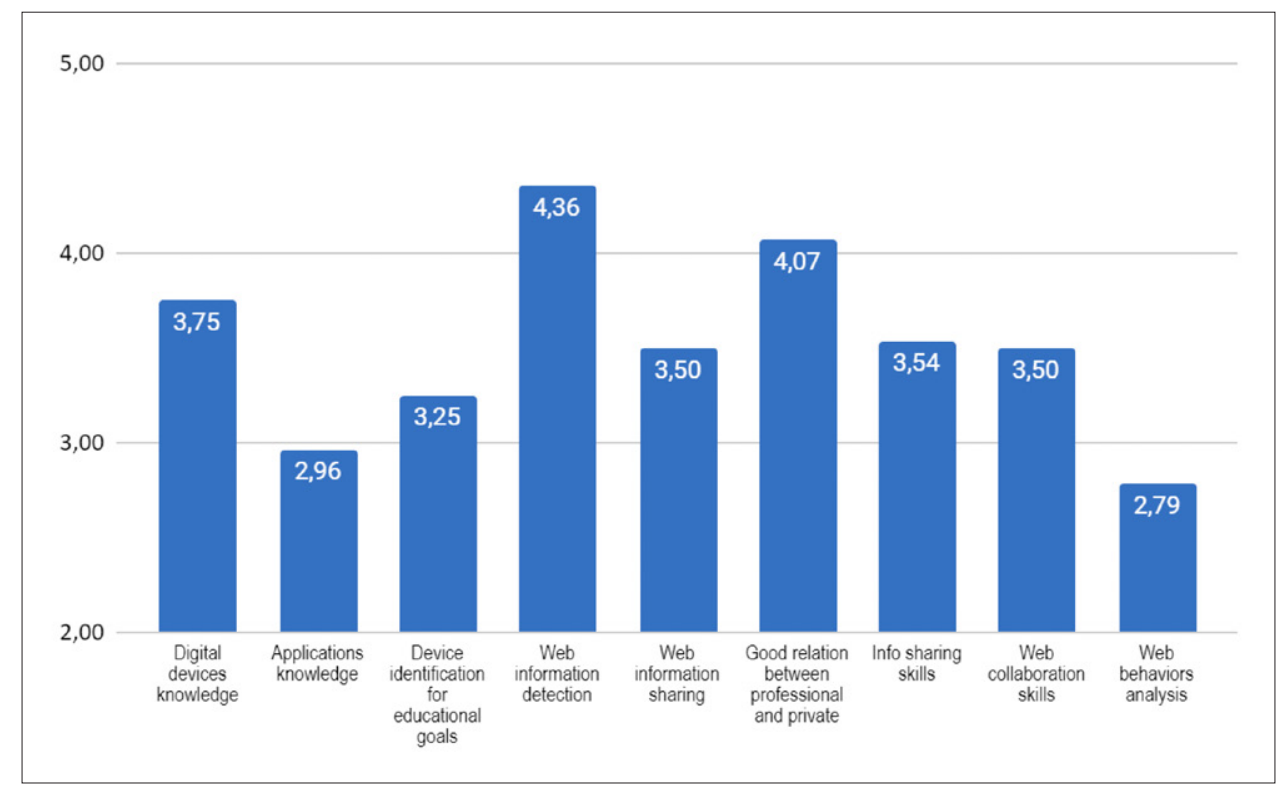

Fig. 3. Digital competence self-evaluation ( $\mu$ on a scale of 1-6) (source: initial questionnaire)

Data about the question 'Reflecting on the design of your training interventions, please identify the six most important elements for you' (using a scale from 1 to 6 , where $1=$ not at all, $6=$ completely) are summarised in Table 2. 


\section{Design for learning in the third space: opportunities and challenges}

Ferrari,S., Triacca, S., Braga,G.

Referring to the five educational elements based on the third-space pedagogy, the following can be stated:

- Peering. Participants recognised the importance of learner's empowerment and learner's pro-activity in the learning process: 'Getting people work in small groups focused on debate and discussion' was considered the most important characteristic of a good lesson (11.90\%) and 'Enabling spaces for peer support' was also one of the most popular (5.95\%). On the other side, they considered 'Promoting peer evaluation' as not important (0.60\%); anyhow, low rates were also obtained for 'Generating conditions that activate students as a "critical friend" towards their peers' $(3.57 \%)$.

- Experiential orientation. The feature most frequently chosen was to have a 'testimonial' for the treated argument, to actively interact with (6.55\%). Only one of those highlighted characteristics was fully in charge of the teacher: to involve students in a significant experience to improve learning commitment.

- Motivation. An educational approach that looks to the future, proposing visions and scenarios to inspire people's learning can be identified by classes based on curiosity and discovery and teachings that would affect the perception that students have of themselves. In this case, it is not fully true: items pertaining to 'motivation' were the least chosen among the five elements (cluster 11.9\%). Also, 7.14\% believed that 'Designing the proposal based on a curiosity and discovery approach' is an important feature for their lessons, but only three educators (1.79\%) chose the item 'Encouraging students proposing challenges' (2.98\%).

- Pleasure of making together. 'Getting people work in small groups', not for discussing, but with the goal of making some kind of artefacts, was important for $4.76 \%$ of respondents, and 'Implementing spaces for discussion and debate in a large group', involving the whole class or other classes, was chosen by $5.36 \%$, as 'Proposing forms of exchange among students between one meeting and another', a way to continue to stay engaged beyond classroom space and time.

- Sociomateriality. In line with the digital skills self-assessment (Fig. 3), only three (1.79\%) considered 'Offering students the use of digital devices and applications' or 'Allowing students to propose work tools and types of feasible products' $(2.98 \%)$ as important, thus limiting youngsters to bring in a formal context knowledge and expertise gained elsewhere. Even 'Proposing a playful-creative approach'was not considered an element to invest in (3.57\%), while for eight respondents $(4.76 \%)$, storytelling was taken into account as a technique to rework the training experience.

Table 2. The importance assigned to third-space elements by Caritas operators (source: initial questionnaire)

\begin{tabular}{|c|c|c|c|c|}
\hline Cluster & Elements & N. & $\%$ & $\%$ cluster \\
\hline \multirow[t]{4}{*}{ Peering } & Enabling spaces / methods for peer support & 10 & 5,95 & 22,0 \\
\hline & Getting people work in small groups focussed on debate and discussion & 20 & 11,90 & \\
\hline & $\begin{array}{l}\text { Generating conditions that activate students as a "critical friend" towards } \\
\text { their peers (commenting products, asking stimulating questions in order to } \\
\text { encourage the adoption of different points of view) }\end{array}$ & 6 & 3,57 & \\
\hline & Promoting forms of peer evaluation & 1 & 0,60 & \\
\hline \multirow[t]{4}{*}{ Experiential orientation } & Presenting significant experiences to students & 12 & 7,14 & 24,4 \\
\hline & Activating moments of discussion with privileged witnesses & 11 & 6,55 & \\
\hline & Providing students with the possibility of practising & 9 & 5,36 & \\
\hline & Fostering the sharing of meaningful experiences lived by students & 9 & 5,36 & \\
\hline \multirow[t]{3}{*}{ Motivation } & Designing the proposal based on a curiosity and discovery approach & 12 & 7,14 & 11,9 \\
\hline & $\begin{array}{l}\text { Providing moments in which explaining the impact of the proposed work } \\
\text { on the student's identity }\end{array}$ & 5 & 2,98 & \\
\hline & Encouraging students proposing challenges & 3 & 1,79 & \\
\hline \multirow[t]{3}{*}{ Pleasure of making together } & Getting people work in small groups & 8 & 4,76 & 15,5 \\
\hline & $\begin{array}{l}\text { Implementing spaces for discussion and debate in a large group (group } \\
\text { class or interclass) }\end{array}$ & 9 & 5,36 & \\
\hline & $\begin{array}{l}\text { Generating / proposing forms of exchange among students between one } \\
\text { meeting and another }\end{array}$ & 9 & 5,36 & \\
\hline \multirow[t]{4}{*}{ Sociomateriality } & Allowing students to propose work tools and types of feasible products & 5 & 2,98 & 13,1 \\
\hline & Proposing a playful-creative approach & 6 & 3,57 & \\
\hline & Using storytelling techniques to rework the training experience & 8 & 4,76 & \\
\hline & Offering students the use of digital devices and applications & 3 & 1,79 & \\
\hline Unselected & n.r. & 22 & 13,10 & 13,1 \\
\hline
\end{tabular}




\section{Design for learning in the third space: opportunities and challenges}

Ferrari,S., Triacca, S., Braga,G.

In the next question, we asked the participants to reflect on the same elements, specifying the degree of activation of them in their practices, using a scale from 1 to 6 , where $1=$ not at all and $6=$ completely. They described themselves as not so good in using these methods: a low $\mu=2.40$ represents their ability to create peer-to-peer settings and the other elements are in a median position (Fig. 4).

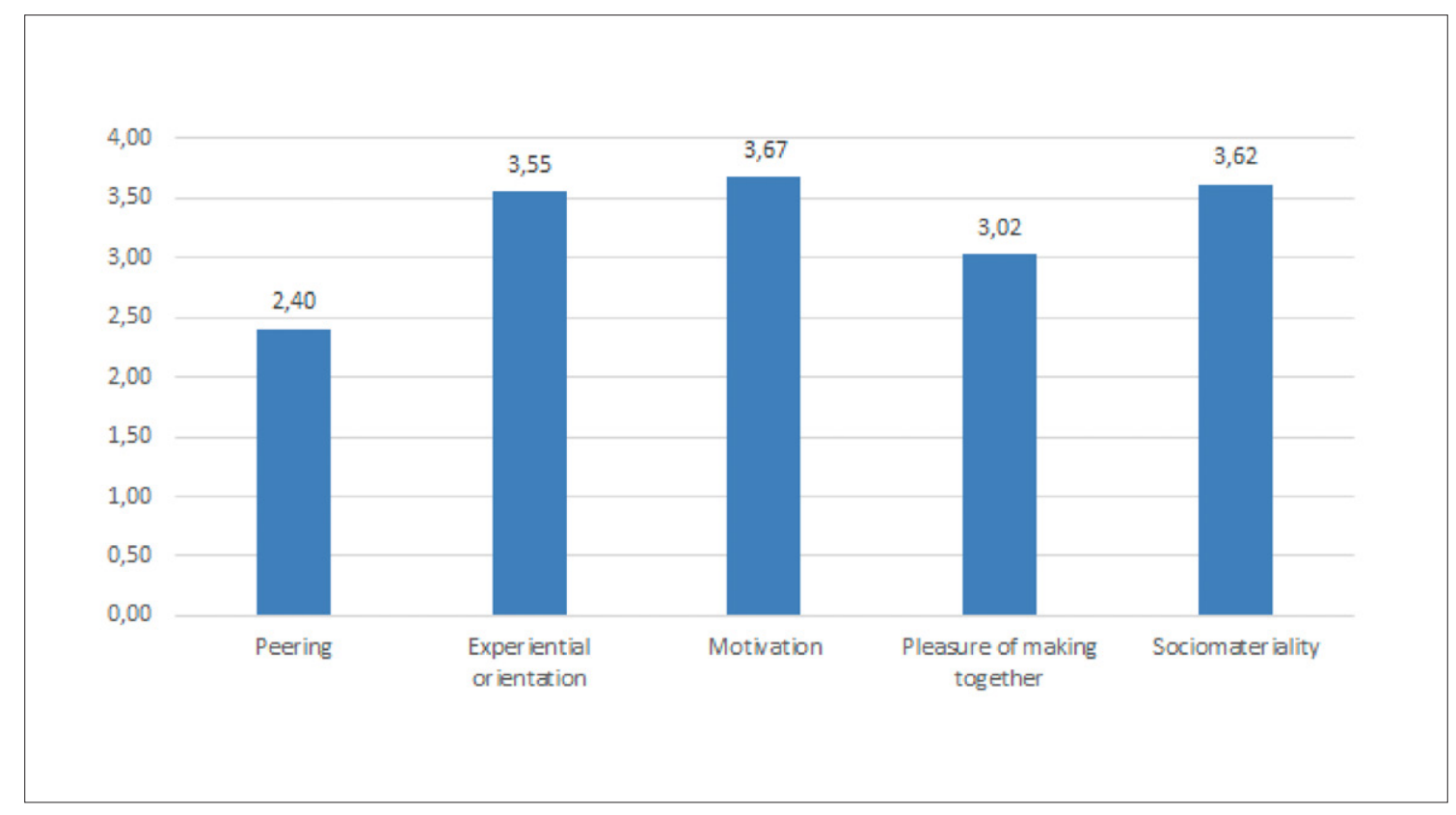

Fig. 4. Self-evaluation of the degree of activation of elements ( $\mu$ on a scale of 1-6)

As a matter of fact, Caritas operators work inside and outside school; they are not satisfied with school spaces, but they have resources to bring other spaces inside the school. They work on transversal skills and are accustomed to cross boundaries; but they are still quite traditional in the way they operate, not so keen on loosening control on the students and more focused on the past than future. They do not show a solid digital competence; but they declare an encouraging interest and basic skills for a digital technology adoption.

Starting from the initial questionnaire data analysis, the accompanying plan designed in the fourth stage and implemented in the fifth is based on the adoption of the BLEC model (Rivoltella \& Modenini, 2012), drawn up by CREMIT, consisting of three structural features:

- The BL of Blended: Our Blended Education model, in the evolved sense of the term (Ardizzone \& Rivoltella, 2004), is defined not only by the coexistence of different teaching situations (asynchronous and synchronous sessions), but also by the mix of methodologies and heterogeneous tools such as webinars, case studies, activities and discussion.

- The E of E-tivity: The qualifying element of the proposal is represented by e-tivities, which are online activities consisting of short tasks that the learner is required to complete to practice individually or in small groups (Salmon, 2002).

- The C of Coaching: In our model, the coach is an expert whose function is midway between that of the e-tutor (Rivoltella, 2006), who provides cognitive and emotional support, and that of the consultant who accompanies professionals training, promoting the integration of theoretical work with that of direct practice.

As can be guessed, '[...] the training exceeds the model of cultural transmission and is mostly oriented toward the design format, encouraging the weld between the time of cultural elaboration and reflection with that of the action in context' (Triacca et al., 2014, p. 115). Furthermore, in this model, CREMIT conceptualises digital as a constitutive element that hybridises practices.

The main focus of the accompanying plan is sociomateriality: on the one hand, for rethinking traditional on-site training formats to face the challenges of the Covid-19 health emergency and on the other, because in the questionnaire, it was considered one of the least important elements to include in the design process of the training interventions. Instead, we assume that investing in sociomateriality will allow Caritas Ambrosiana's educators to engage youngsters, thanks to their digital practices, and that working on digital tools should impact the pleasure of doing together and motivation. We will focus on the other elements (peering, experiential orientation, motivation, pleasure of making together) in the next phases (stages 6-8).

We proposed a path in three modules, each organised in:

- a webinar managed by CREMIT, starting from an initial theoretical framework on the specific topic and then deepening this content in a workshop. At the end of the webinar, a design e-tivity was launched in view of the next meeting and

- after about 15 days, participants were involved in a self-managed meeting in which on the mandate given by CREMIT, they developed design artefacts, commented and discussed in the following webinar (Fig. 5). 


\section{Design for learning in the third space: opportunities and challenges}

Ferrari,S., Triacca, S., Braga,G.

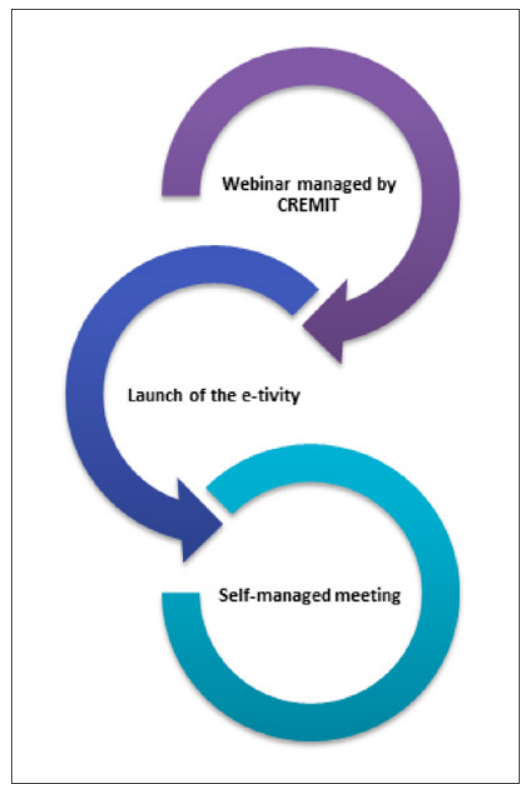

Fig. 5. Standard module structure

Table 3 summarises the themes of the modules and their related e-tivities.

Table 3. The accompanying plan and the e-tivities

\begin{tabular}{ll}
\hline Module & E-tivity \\
\hline Online synchronous communication: from the class to large groups & Design a webinar (storyboard) \\
Mixing synchronous and asynchronous interventions for classes & Design a blended proposal \\
Apps to support digital activity & Technologically implement the blended proposal \\
\hline
\end{tabular}

The analysis of the blended proposals will be dealt with in depth in the next paragraph.

\section{Design practices analysis}

Analysis was conducted on design 'unplugged' practices and on blended practices (after training session) using the keywords related to Potter and McDougall's third-space theory (2017), assuming the way Rivoltella focuses them in education (2020): peering, experiential orientation, motivation, pleasure of making together, sociomateriality. Referring the third-space theory, we assume that working on sociomateriality ' $[1 / 4]$ implies that we should try to understand more about how meaning is made in respect to the interactions between learners and artefacts, bodies and spaces, just as much as it is from their lived experience in wider culture' (Potter \& McDougall, 2017, p. 9). This means that the other elements (peering, experiential orientation, motivation, pleasure of making together) should not be weakened in the educational projects.

A different weight depending on occurrences has been given, using a scale of 0-7: weight is reproduced in the tab by a darker blue colour in the correspondent cell. The results of the analysis are shown in Fig. 6.

As expected, sociomateriality had a significant growth and is now well represented in the design practices: use of digital apps is in almost every document; proposals of games and creative tasks are a second clear change (ice-breaking activities, presentation games, challenges are frequently considered). There are also some examples of creative tasks such as telling stories and making artefacts.

Working groups and self-reflection are maintained and integrated with other methods in the post-training projects. Participants understood that digital tools allow collaborative and cooperative processes and support the collection of individual reflection.

Analysing the other educational elements based on the third space, we highlight the following:

- Peering orientation is preserved and 'Getting people to work in small groups focused on debate and discussion' increases. What is still missing is a real offer of spaces designed for educational relationships between peers.

- Relating to pleasure of making together, participants planned digital making activities for youngsters. The necessity to social distancing, due to the Covid-19 emergency, impacted on organising big group debates, which decreased, overall, in primary school contexts.

- Motivation does not change in design practices. Reflective activities, mainly described in an abstract and general manner, are better defined and their impact on their own experience is more focused over the course attended. Methods to engage participants and to support learning motivation (challenges, explorations, research, etc.) are recognised as valuable and requested to be developed in the future. 


\section{Design for learning in the third space: opportunities and challenges}

Ferrari,S., Triacca, S., Braga,G.

- Experiential orientation decreases only in 'Presenting significant experiences to students'. The positive habits of involving testimonials for real experienced storytelling seem to benefit from digital opportunities. Instead, low digital competence of Caritas educators did not allow them to feel confident to enable meaningful relationships with classroom even at a distance.

These third-space pedagogical elements seem not to be unfairly penalised by digitalisation of educator's competence.

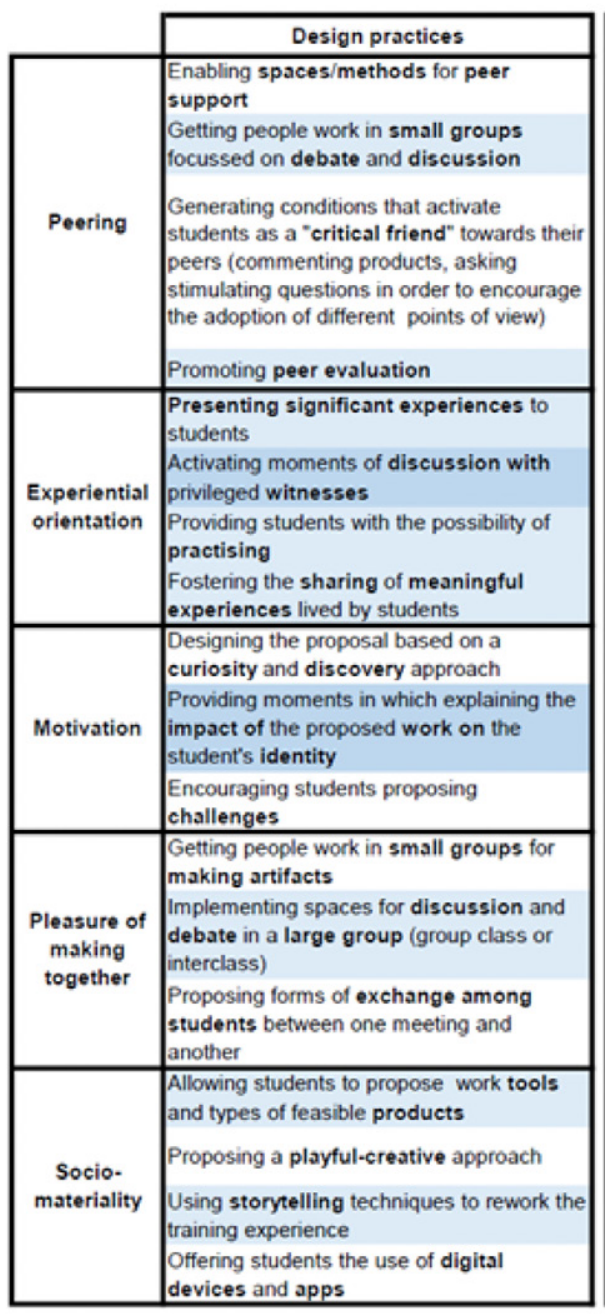

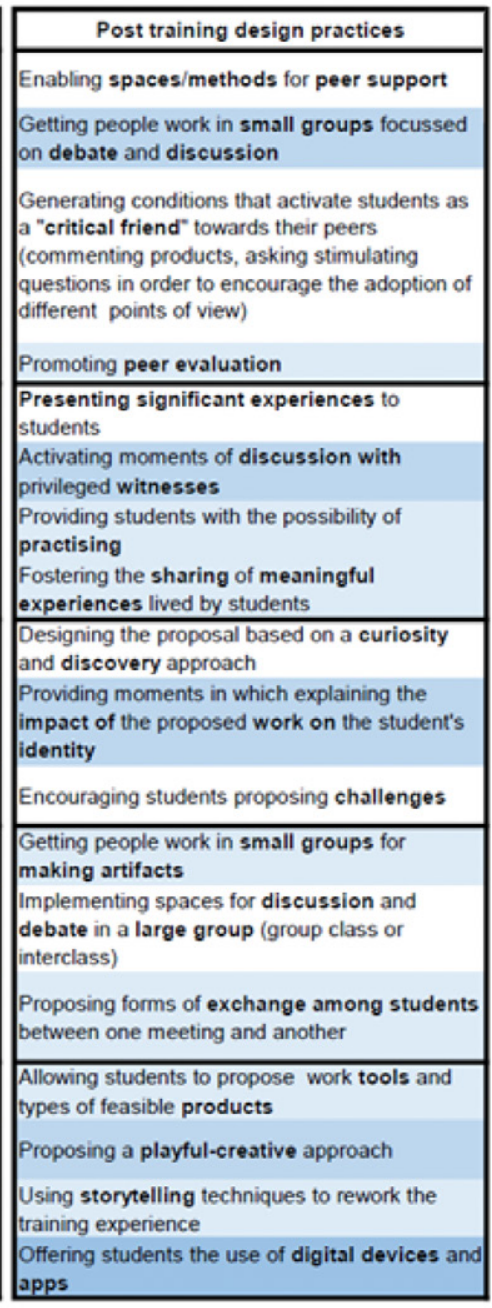

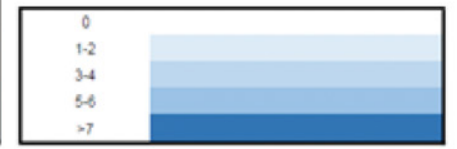

Fig. 6. Initial projects and post-training project analysis

\section{Conclusions}

The research process is in progress. What we have done so far has allowed us to show a way to guide non-formal educational contexts to generate third space in the second one, identifying the key elements of the third-space pedagogy and including them in the design for learning. Potter and McDougall (2017) use some keywords to define activities that enable third space: contested, agentive, negotiated, lived experience, horizontal, subverting power relations, manifestation of popular culture, intentioned digital.

We focused the training on embedding digital media into Caritas educators' practices to enable a more porous exchange of experiences and expertise between students, educators and the school curriculum. It was a challenge to stimulate the 'reflective practitioner' (Schon, 1991) sociomateriality of the digital and update their competences. 'How might these events which take place on screen, between social actors and artefacts in a range of locations become part of the pedagogical frame? What kinds of things might people do? What kinds of interactions are possible formally organized spaces?' (Potter \& McDougall, 2017, p. 35).

In the next stage of the action research, we are going to monitor the change: the educators will lead the reviewed projects in school. The aim is to check if they will be generative of dialogue, construction and creativity (Potter \& McDougall, 2017, p. 43) in the classroom and to what extent they affect school pedagogies. 


\section{Design for learning in the third space: opportunities and challenges}

Ferrari,S., Triacca, S., Braga,G.

\section{Authors' contributions}

This article has been developed jointly by the authors. Simona Ferrari wrote ' 1 . Towards a third-space pedagogy' and '2.1. Research plan and tools'. Serena Triacca wrote '2.2 Data analysis for designing the accompanying plan with the BLEC model'. Gianluca Braga wrote ‘3. Design practices analysis'. ‘4. Conclusions’ has been written jointly.

\section{References}

Ardizzone, P., Rivoltella, P.C. (2004). Didattiche per l'e-learning. Roma: Carocci.

Bhabha, H.K. (1990). The Third Space. In J. Rutherford (Eds.), Identity, Community, Culture, Difference (pp. 207-221). London: Lawrence \& Wishart.

Bhabha, H.K. (1994). The Location of Culture. London: Routledge.

Bassey, M. (1998). Action research for improving educational practice. In R. Halsall, Teacher Research and School Improvement: Opening Doors from the Inside (pp. 93-108). Buckingham: Open University Press.

Bowen, G. A. (2009). Document Analysis as a Qualitative Research Method. Qualitative Research Journal, 9, 27-40.

Costello, P. J. M. (2003). Action research. London: Continuum.

Denscombe, M. (1998). The Good Research Guide for SmallScale Social Research Projects, Buckingham: Open University Press

Field, J. (2000). Lifelong learning and the new educational order. London: Trentham Books.

Gaffney, G. (2006). What is a Cultural Probe? Retrieved at https://tinyurl.com/y4rlkf76

Gaver, W., Dunne, A., Pacenti, E. (1999). Design: Cultural Probes. Interactions, 6, 21-29. https://doi. org/10.1145/291224.291235

Hamadache, A. (1991). Non-formal education. Prospects, 21(1), 109-124.

Hoppers, W. (2006). Non-Formal Education and Basic Education Reform: A Conceptual Review. Paris: International Institute for Educational Planning (IIEP) UNESCO.

Lincoln Y., Guba E. (1985). Naturalistic Inquiry. Beverly Hills, CA: Sage.

McDougall, J., \& Potter, J. (2015). Curating media learning: Towards a porous expertise. E-Learning and Digital Media, 12, 199-211. https://doi.org/10.1177/2042753015581975

Potter, J., McDougall, J. (2017). Digital Media, Culture and Education: Theorising Third Space Literacies. London, Palgrave Macmillan.

Rivoltella, P.C. (2020). New Literacies. Essere a scuola, 6(2), 1-2.

Rivoltella, P.C. (Ed.) (2006). E-tutor. Profilo, metodi e strumenti. Roma: Carocci.

Rivoltella, P.C., Modenini, M. (Eds) (2012). La lavagna sul comodino. Milano: Vita\&Pensiero.

Salmon, G. (2002). E-tivities. The key to active online learning. London: Routledge.

Savagnone, A. (2009). La pedagogia dei fatti: per un cammino educativo alla carità. In G. Perego (Eds.), Caritas Italiana, La Chiesa della carità (pp. 275-299). Bologna: EDB.

Schon, D. A. (1987). Educating the Reflective Practitioner. San Francisco: Jossey-Bass Publishers.

Schon, D. A. (1991). The Reflective Practitioner: How Professionals Think in Action. Aldershot: Avebury.

Soja, E.W. (1996). Thirdspace: Journeys to Los Angeles and Other Real-And-Imagined Places. Malden, MA: Blackwell Publishing

Spiridonidou, A., Kampi, I., Chorianopoulos, K. (2010), Exploring Everyday Life in Remote Schools: A Large-scale Study with Cultural Probes and Affinity Diagrams. Workshop on Digital Technologies and Marginalized Youth, IDC 2010.

Street, B. (2003). What's "new" in new literacy studies? Critical approaches to literacy in theory and practice. Current Issues in Comparative Education, 5, 77-91.

Triacca, S., Ferrari, S., Rivoltella, P.C. (2014). Coaching and Teachers Training. An Overview of "HSH" Project in Lombardy. REM Research on Education and Media, 7 (1), Lecce: Pensa Multimedia, 111-119.

Woolf, S. B. (2019). Exploring pedagogies to elevate inquiry: teaching action research in the third space. Educational Action Research, 28:4, 579-596. https://doi.org/10.1080/09650792.2019.1629975 